\title{
Determinants of soil respiration in a semi-arid savanna ecosystem, Kruger National Park, South Africa
}

\author{
Authors: \\ Rudzani A. Makhado ${ }^{1,2}$ \\ Robert J. Scholes ${ }^{1}$ \\ Affiliations: \\ ${ }^{1}$ Natural Resources and the \\ Environment, CSIR, \\ South Africa \\ ${ }^{2}$ Research and Evaluation, \\ Limpopo Legislature, \\ South Africa \\ Correspondence to: \\ Robert Scholes \\ Email: \\ bscholes@csir.co.za \\ Postal address: \\ PO Box 395, Pretoria 0001 \\ South Africa \\ Dates: \\ Received: 24 Jan. 2011 \\ Accepted: 19 May 2011 \\ Published: 08 Sept. 2011 \\ How to cite this article: \\ Makhado, R.A. \& Scholes, \\ R.J., 2011, 'Determinants of \\ soil respiration in a semi-arid \\ savanna ecosystem, Kruger \\ National Park, South Africa', \\ Koedoe 53(1), Art. \#1041, 8 \\ pages. doi:10.4102/koedoe. \\ v53i1.1041
}

Soil respiration, which is a combination of root respiration and microbial respiration, represents one of the main carbon fluxes in savannas. However, it is remarkable how little is known about these components - regarding either process-level mechanisms or quantitative estimates, especially in savanna ecosystems. Given the extensive area of savannas worldwide, this limits our ability to understand and predict the critical changes in the global carbon budget that underlie the phenomenon of global climate change. From May 2000 to April 2001, bi-weekly soil respiration measurements from two savanna types were made in 14 sampling collars (diameter $=100 \mathrm{~mm}$ ), using a PP Systems EGM-2 respirometer. Results indicated that there was a difference in the rate of respiration between the more clayey Acacia and sandier Combretum savanna soils $(p=0.028)$. The mean $( \pm$ s.d.) soil respiration in the Acacia savanna was $0.540 \mathrm{~g} / \mathrm{m}^{2} / \mathrm{h} \pm 0.419 \mathrm{~g} / \mathrm{m}^{2} / \mathrm{h}$, whilst it was $0.484 \mathrm{~g} / \mathrm{m}^{2} / \mathrm{h} \pm$ $0.383 \mathrm{~g} / \mathrm{m}^{2} / \mathrm{h}$ in the Combretum savanna. We also found that soil respiration was sensitive to soil moisture and soil temperature. The rate of soil respiration at both sites rose to a maximum when soil temperature was at $28{ }^{\circ} \mathrm{C}$ and declined at higher temperatures, despite different temperature sensitivities. Soil respiration increased approximately linearly with an increase of soil moisture. In both savanna sites soil is subject to a combination of high temperature and water stress, which controls the fluxes of soil carbon dioxide. We found that the two sites differed significantly in their soil moisture characteristics $(p<0.0001)$ but not with regard to temperature ( $p=0.141)$, which implies that soil moisture is the main factor responsible for the differences in respiration between Acacia and Combretum savannas.

Conservation implications: It is argued for many protected areas that they perform a climate change buffering function. Knowing the soil respiration rate and determining its controlling factors contribute to improved understanding of whether protected areas will be net sources or sinks of carbon in the future.

\section{Introduction}

The sun's energy, captured by plants through photosynthesis, is used to combine atmospheric carbon dioxide $\left(\mathrm{CO}_{2}\right)$ and water from the soil into carbohydrates. At ecosystem scale, this process is called gross primary production (GPP) (Mäkelä et al. 2008; Roxburgh et al. 2005). The organic molecules, in their various forms, are subsequently oxidised during the process of respiration, releasing $\mathrm{CO}_{2}$, water and energy. Respiration can take several forms: the plant itself respires (autotrophic respiration) in order to grow and metabolise, the microbes in the soil respire as they break down soil organic matter (SOM), some plant parts are eaten by herbivores and some plant residues are consumed by fire. It is important to be able to measure or estimate $R_{a}$ in order to calculate net primary productivity (NPP), the carbon that appears as an increase in plant mass and the energy that is available to power the rest of the ecosystem, as shown in Equation 1. The exudates and volatile organic carbon (VOC) terms are typically much smaller than autotrophic respiration but in savannas both may be considerable. Savannas regularly experience a combination of high temperatures, high solar radiation and water stress, which leads to large effluxes of isoprene and monoterpenes - typically about $5 \%$ of GPP, but under exceptional circumstances as much as $40 \%$ (Otter, Guenther \& Greenberg 2002).

$\mathrm{GPP}=\mathrm{NPP}+\mathrm{R}_{\mathrm{a}}+$ exudates $+\mathrm{VOC}$,

[Eqn 1]

with $R_{a}$ representing autotrophic respiration.

Globally, terrestrial GPP is estimated at $120 \mathrm{Pg} \mathrm{C} \mathrm{yr}^{-1}$ and NPP at $60 \mathrm{Pg} \mathrm{C} \mathrm{yr}^{-1}$ (Houghton 1995; IPCC 2001). In the long term, in a steady-state system, respiration from the entire ecosystem (which includes autotrophic respiration, as well as the respiration components due to herbivore activity and fire) should be approximately equal to GPP; that is, net biome production should 
be approximately zero. The global terrestrial ecosystem as a whole is currently not in steady state: it represents a net sink

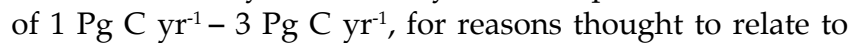
rising atmospheric $\mathrm{CO}_{2}$ levels, elevated nitrogen availability, climate change and ongoing change in disturbance regimes.

Autotrophic respiration is widely estimated to amount to about half of the GPP (Prentice et al. 2001; Watson et al. 2000). A large part of this occurs belowground from the roots themselves or from root exudates, which have been variously estimated as constituting $10 \%-20 \%$ of the GPP. However, in whole soil it is technically very difficult to differentiate between the respiration from the roots themselves versus that of heterotrophic respiration of soil microbes, a portion of which comes from the oxidation of root exudates.

Soil respiration, the combination of root and microbial respiration, typically represents the single largest carbon flux from savanna ecosystems to the atmosphere. At a global scale, soil respiration is the second-largest terrestrial carbon

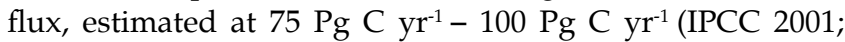
Raich \& Potter 1995), 79.3 Pg C yr $\mathrm{yr}^{-1}$ - 81.8 $\mathrm{Pg} \mathrm{C} \mathrm{yr}^{-1}$ (Raich, Potter \& Bhagawati 2002) or $98 \mathrm{Pg} \mathrm{C} \pm 12 \mathrm{Pg} \mathrm{C}$, increasing at $0.1 \mathrm{Pg} \mathrm{C} \mathrm{yr}^{-1}$ (Bond-Lamberty \& Thomson 2010). High uncertainty in soil respiration estimates is an indication of the imprecision with which it is known globally. Such variation is due to the spatial and temporal variability of soil respiration and the inability to measure the parameter remotely remains a significant constraint to regional and global evaluations of the feedback potential that soil processes have on the global carbon cycle (Reichstein \& Beer 2008).

Soil respiration responds to a suite of drivers, including temperature, moisture and vegetation productivity, all at different spatial and temporal scales (Ågren et al. 1996; Reichstein et al. 2003; Vincent et al. 2006; Webster et al. 2008). Many studies show that soil respiration is sensitive to climatic variability, expressed through soil moisture and temperature (Anderson 1995; Conant et al. 2004; Davidson, Belk \& Boone 1998; Fan et al. 1995; Jarvis \& Leverenz 1983; Lavigne et al. 1997; Raich \& Schlesinger 1992; Veenendaal, Kolle \& Lloyd 2004; Wang et al. 2010). Global warming is generally predicted to reduce ecosystem carbon storage by increasing respiration, especially of soils (Conant et al. 2004; Houghton \& Woodwell 1989; Scholes \& Walker 1993). Cooling in the past increased carbon storage (Schimel 1995), and cool areas generally have greater soil carbon stores than warm areas. Various studies have shown that the temperature sensitivity of respiration (conventionally expressed as $Q_{10}$, the ratio of the rate at a given temperature to the rate ten degrees cooler) declines from the boreal to the temperate zone (e.g. Chen \& Tian 2005; Peng et al. 2009; Raich \& Schlesinger 1992; Reichstein et al. 2003), but it is still unclear if this represents a long-term evolutionary adaptation, a short-term acclimation or a difference in substrate quality (Kirschbaum 1995; Townsend, Vitousek \& Holland 1992; Zheng et al. 2009, Wang et al. 2010). Soil respiration is broadly proportional to the amount of oxidisable substrate that is present (SOM, including humified material, finely divided soil litter such as dead roots, exudates and recently dead microbes), but is also affected by the proportions of SOM in various forms, because they differ with regard to the ease with which they can be oxidised. In a warm, semi-arid environment, availability of soil moisture is the controlling factor for soil respiration (e.g. Xu, Baldocchi \& Tang 2004; Zhang et al. 2003).

Given that the various processes of respiration are just as important as photosynthesis in determining the carbon balance in an ecosystem, it is remarkable how little is known about them, with reference to either process-level mechanisms or quantitative estimates, especially in savanna ecosystems. Ecosystem warming experiments (Luo, Wan \& Hui 2001), modelling analysis (Raich et al. 2002) and fundamental biokinetics (Davidson \& Janssens 2006) all suggest that soil respiration should change with climate. The relative contributions of these mechanisms have been difficult to confirm observationally because of the high spatial variability of soil respiration, inaccessibility of the soil medium and the difficulty of measuring respiration continuously and at large scales, for instance by using remote sensing (BondLamberty \& Thomson 2010; Jones \& Cox 2001). Modelling efforts that link observations of soil respiration at different scales are making important contributions to understanding the variability of the parameter at local, regional and global scales (Reichstein \& Beer 2008).

This paper reports the results of a year-long series of measurements of soil respiration conducted at the flux site at Skukuza, Kruger National Park, South Africa. Data such as these can help construct models of respiration in semi-arid savannas. The objectives of the study were to:

- determine the effect of soil temperature and moisture on soil respiration

- determine whether there is a difference in soil respiration between fine-leaved Acacia and broad-leaved Combretum savannas

- determine whether there is a relationship between soil respiration and measures of carbon assimilation in the savannas, such as the fraction of absorbed photosynthetically active radiation (FAPAR).

\section{Method \\ Study area}

The study site was located at the Skukuza flux tower, in a semi-arid savanna ecosystem. The Skukuza flux tower is found in the southern part of the Kruger National Park. The exact location was $25^{\circ} 01.184^{\prime} \mathrm{S}, 31^{\circ} 29.813^{\prime} \mathrm{E}$ and oriented true north at an altitude of $365 \mathrm{~m}$ above sea level (Scholes et al. 2001). As is common in semi-arid savannas on granitic geologies, the undulating landscape results in a catena with sandy crests and clay-rich bottomlands. The flux tower is located at the ecotone between the broad-leaved (Combretum) savanna, which occupies the crests, and the fine-leaved (Acacia) savanna on the more clayey bottomlands (Scholes et al. 2001).

The area is characterised by shallow soils, seldom deeper than $50 \mathrm{~cm}$ and underlain by granite rocks of the Basement complex (Nelspruit Suite) intruded by mafic dykes of both pre-Karoo and post-Karoo age (Venter 1990). This gives rise 
to a landscape of moderately undulating plains. The crests of the slopes are well-drained interfluvial areas with slope angles seldom more than $10 \%$. The soil here is shallow and stony, presenting as a brownish, coarse sandy loam. Rock outcrops make up a small percentage of the landscape. At mid-slope there are moderately to poorly drained slopes with slope angles of between $1 \%$ and $13 \%$. Here one finds shallow, grey, eutrophic, coarse sand over weathered rock or greyish-brown clay. At the foot of the slope there are poorly to moderately drained slopes with angles of between $1 \%$ and $9 \%$. The soils here are paraduplex sandy clay, often associated with mafic dykes. They are shallow to moderately deep red and brown eutrophic loams. Pedocutanic clays also occur (Venter 1990).

The site has a subtropical climate, with warm to hot summers and mild winters. Temperatures can reach $44{ }^{\circ} \mathrm{C}$ in the summer, but seldom fall below freezing point in winter. Mean annual rainfall is $547 \mathrm{~mm}$, with an interannual coefficient variation of $30 \%$ (Scholes et al. 2001). Rainfall occurs in the warm summer months. The first rainfall event generally occurs in late September or early October and the last event is usually in April or early May. Fire is a common phenomenon during the six months of the dry winter period, occurring on average once every five years (although the site itself had three fires in the period between 2001 and 2006).

\section{Data collection}

A total of 14 white PVC cylinders (collars), each $100 \mathrm{~mm}$ wide and $70 \mathrm{~mm}$ high, were inserted vertically into the soil to a depth of $5 \mathrm{~mm}$ in February 2000. Half the number of collars (i.e. seven) were placed in the Acacia savanna site, whilst the remaining seven were placed in the Combretum savanna site. Individual collars in each cluster were approximately $3 \mathrm{~m}$ apart.

Soil respiration measurements were performed in each collar bi-weekly over one year, from May 2000 to April 2001, using a closed-system soil respirometer (PP Systems EGM-2 IRGA, Amesbury, MA), with a ventilated, insulated SRC-1 soil chamber (volume $=150 \mathrm{~cm}^{3}$ ). Corresponding soil temperature and moisture measurements were also made for each soil respiration measurement. Both soil temperature and soil moisture were measured at a depth of $100 \mathrm{~mm}$, using a thermocouple probe (Campell Scientific) and a time-domain reflectometer instrument (Hydrosense, Campbell Scientific), respectively.

Data regarding FAPAR, an index of aboveground plant activity, were derived from the NASA SeaWifs satellite for the period May 2000 to April 2001. SeaWifs data were used because of their high spatial resolution $(4.5 \mathrm{~km}$ in global mode).

\section{Data analysis}

Data were captured in a spreadsheet, which was imported to STATISTICA (version 7.1) for statistical analysis. Twodimensional scatterplots fitted with polynomial regression curves were used to analyse the effect of soil temperature and moisture on soil respiration. Two-dimensional mean plots (box-and-whisker) were used to analyse the mean monthly respiration and FAPAR. Three-dimensional scatterplots were used to analyse the relationship between soil respiration, temperature and moisture. A multiple regression $(z / x y)$ function was used to compute the effect of soil temperature and moisture on respiration. A single-factor analysis of variance (ANOVA) was used to examine statistically significant differences between means. Temperature sensitivity $\left(Q_{10}\right)$ of soil respiration was determined according to Equation 2:

$Q_{10}=\left[\frac{R_{2}}{R_{1}}\right]^{\left\lfloor\frac{10}{T_{2}-T_{1}}\right]}$

where $Q_{10}$ is the factor by which the reaction rate increases when the temperature is raised by $10{ }^{\circ} \mathrm{C}, R_{1}$ is the measured reaction rate at temperature $T_{1}$ and $R_{2}$ is the measured reaction rate at temperature $T_{2}$

\section{Results}

\section{Effects of soil temperature on the rate of soil respiration}

The effect of soil temperature on the rate of respiration is shown in Figures $1 \mathrm{a}$ and $1 \mathrm{~b}$. No soil temperature data below $10^{\circ} \mathrm{C}$ were recorded at either sampling site. The small number of records between $11{ }^{\circ} \mathrm{C}$ and $12{ }^{\circ} \mathrm{C}$ meant that the increase in the rate of soil respiration between these temperatures in both the Acacia and Combretum savannas was not statistically significant ( $p=0.141$; see Table 1$)$. The highest mean monthly respiration rates in the savannas were measured between October and December, when the mean monthly soil temperature was between $24^{\circ} \mathrm{C}$ and $28^{\circ} \mathrm{C}$ (Table 1 ).

Maximum respiration rates were observed in November, with a mean of $1.053 \mathrm{~g} \mathrm{CO}_{2} / \mathrm{m}^{2} / \mathrm{h} \pm 0.575 \mathrm{~g} \mathrm{CO}_{2} / \mathrm{m}^{2} / \mathrm{h}$ at the Acacia site and $0.831 \mathrm{~g} \mathrm{CO}_{2} / \mathrm{m}^{2} / \mathrm{h} \pm 0.329 \mathrm{~g} \mathrm{CO}_{2} / \mathrm{m}^{2} / \mathrm{h}$ at the Combretum site. The mean monthly soil temperature for November in both the Acacia and Combretum savannas was about $24{ }^{\circ} \mathrm{C}$ (see Table 1 ). The mean $Q_{10}$ values were 2.22 for soil temperatures between $11.4{ }^{\circ} \mathrm{C}$ and $21.4{ }^{\circ} \mathrm{C}, 2.65$ for soil temperatures between $21.4{ }^{\circ} \mathrm{C}$ and $31.4{ }^{\circ} \mathrm{C}$, and 0.59 for soil temperatures between $31.4{ }^{\circ} \mathrm{C}$ and $44.8{ }^{\circ} \mathrm{C}$ at the Acacia site. For the Combretum site, mean $Q_{10}$ values were 3.07 for soil temperature between $12.6{ }^{\circ} \mathrm{C}$ and $22.6{ }^{\circ} \mathrm{C}, 1.64$ for temperatures between $22.6{ }^{\circ} \mathrm{C}$ and $32.6{ }^{\circ} \mathrm{C}$, and 1.25 for temperatures between $32.4^{\circ} \mathrm{C}$ and $37.1^{\circ} \mathrm{C}$. The decrease in $Q_{10}$ values with increasing temperature at both sites shows that soil respiration does not follow a single, exponential response to temperature over the entire range (as is often assumed in respiration models). The rate of increase of respiration with temperature declined when soil temperature rose above $28^{\circ} \mathrm{C}$ (Figures 1a and 1b).

\section{Effects of soil moisture on the rate of soil respiration}

We found that an increase in volumetric soil moisture content had a positive effect on the rate of respiration, as shown in Figures $2 \mathrm{a}$ and $2 \mathrm{~b}$. The highest rate of soil respiration was 
TABLE 1: Mean ( \pm s.d.) monthly effect of soil temperature, moisture and fraction of absorbed photosynthetically active radiation on the rate of soil respiration measured over 12 consecutive months at Skukuza, Kruger National Park, South Africa.

\begin{tabular}{|c|c|c|c|c|c|c|c|c|c|c|c|c|c|c|}
\hline \multirow[t]{3}{*}{ Month } & \multicolumn{4}{|c|}{ Soil temperature $\left({ }^{\circ} \mathrm{C}\right)$} & \multicolumn{4}{|c|}{ Soil moisture (\%) } & \multicolumn{4}{|c|}{ Soil $\mathrm{CO}_{2}$ respiration $\left(\mathrm{g} / \mathrm{m}^{2} / \mathrm{h}\right)$} & \multirow{2}{*}{\multicolumn{2}{|c|}{$\begin{array}{c}\text { FAPAR }(\mu \mathrm{m}) \\
\text { All sites }\end{array}$}} \\
\hline & \multicolumn{2}{|c|}{$\begin{array}{c}\text { Acacia } \\
\text { savanna }\end{array}$} & \multicolumn{2}{|c|}{$\begin{array}{c}\text { Combretum } \\
\text { savanna }\end{array}$} & \multicolumn{2}{|c|}{$\begin{array}{c}\text { Acacia } \\
\text { savanna }\end{array}$} & \multicolumn{2}{|c|}{$\begin{array}{c}\text { Combretum } \\
\text { savanna }\end{array}$} & \multicolumn{2}{|c|}{$\begin{array}{c}\text { Acacia } \\
\text { savanna }\end{array}$} & \multicolumn{2}{|c|}{$\begin{array}{c}\text { Combretum } \\
\text { savanna }\end{array}$} & & \\
\hline & Mean & s.d. & Mean & s.d. & Mean & s.d. & Mean & s.d. & Mean & s.d. & Mean & s.d. & Mean & s.d. \\
\hline Jan & 37.329 & 4.187 & 33.343 & 2.841 & 1.357 & 0.745 & 1.000 & 0.000 & $0.338^{a}$ & 0.131 & $0.351^{\mathrm{a}}$ & 0.191 & 0.342 & 0.039 \\
\hline Feb & 25.914 & 1.427 & 25.010 & 1.468 & 5.357 & 4.997 & 3.500 & 2.432 & $0.538^{\mathrm{b}}$ & 0.357 & $0.558^{b}$ & 0.399 & 0.317 & 0.037 \\
\hline Mar & 26.371 & 2.388 & 26.371 & 2.388 & 3.714 & 2.761 & 2.429 & 1.484 & $0.739^{b}$ & 0.245 & $0.712^{\mathrm{b}}$ & 0.276 & 0.433 & 0.031 \\
\hline Apr & 23.507 & 1.053 & 23.045 & 1.122 & 5.571 & 3.630 & 3.619 & 1.794 & $0.617^{b}$ & 0.227 & $0.559^{b}$ & 0.214 & 0.414 & 0.023 \\
\hline May & 18.311 & 1.706 & 18.130 & 1.189 & 4.357 & 2.938 & 4.821 & 0.993 & $0.568^{b}$ & 0.261 & $0.496^{b}$ & 0.458 & 0.330 & 0.043 \\
\hline Jun & 18.021 & 1.354 & 17.307 & 0.554 & 3.571 & 1.016 & 4.714 & 0.726 & $0.375^{a}$ & 0.217 & $0.305^{a}$ & 0.176 & 0.239 & 0.017 \\
\hline Jul & 16.689 & 2.206 & 16.015 & 1.831 & 2.804 & 1.458 & 3.048 & 1.066 & $0.223^{\mathrm{a}}$ & 0.121 & $0.220^{\mathrm{a}}$ & 0.154 & 0.180 & 0.016 \\
\hline Aug & 19.939 & 1.734 & 19.516 & 1.812 & 1.125 & 0.384 & 1.018 & 0.134 & $0.162^{\mathrm{a}}$ & 0.105 & $0.181^{\mathrm{a}}$ & 0.190 & 0.151 & 0.014 \\
\hline Sep & 22.883 & 1.681 & 23.390 & 1.850 & 1.071 & 0.261 & 1.048 & 0.216 & $0.089^{a}$ & 0.067 & $0.078^{a}$ & 0.052 & 0.146 & 0.023 \\
\hline Oct & 24.493 & 1.311 & 25.257 & 1.609 & 7.286 & 2.351 & 5.405 & 1.326 & $0.834^{c}$ & 0.326 & $0.693^{b}$ & 0.296 & 0.176 & 0.038 \\
\hline Nov & 24.188 & 1.835 & 23.789 & 1.938 & 7.375 & 2.976 & 5.089 & 1.761 & $1.053^{\mathrm{c}}$ & 0.575 & $0.830^{c}$ & 0.329 & 0.407 & 0.087 \\
\hline Dec & 28.364 & 3.520 & 27.332 & 3.296 & 4.679 & 2.639 & 3.607 & 1.873 & $0.851^{c}$ & 0.213 & $0.831^{c}$ & 0.334 & 0.436 & 0.041 \\
\hline Year mean & 22.831 & 4.763 & 22.406 & 4.441 & 4.169 & 3.410 & 3.294 & 2.069 & 0.540 & 0.419 & 0.484 & 0.383 & 0.297 & - \\
\hline Year maximum & 44.800 & - & 37.100 & - & 17.000 & - & 9.000 & - & 2.770 & - & 2.770 & - & 0.551 & - \\
\hline Year minimum & 11.400 & - & 12.600 & - & 1.000 & - & 1.000 & - & 0.010 & - & 0.010 & - & 0.115 & - \\
\hline$p$-value & 0.141 & - & - & - & $<0.0001$ & - & - & - & 0.028 & - & - & - & - & - \\
\hline
\end{tabular}

FAPAR, fraction of absorbed photosynthetically available radiation; s.d., standard deviation.

Symbols represent the seasonal effects of soil temperature, moisture and FAPAR on the rate of soil respiration.

Scale: $0.0-0.49$, low; $0.50-0.75$, moderate; $\geq 0.76$, high.

a, Low respiration.

, Moderate respiration

c, High respiration.
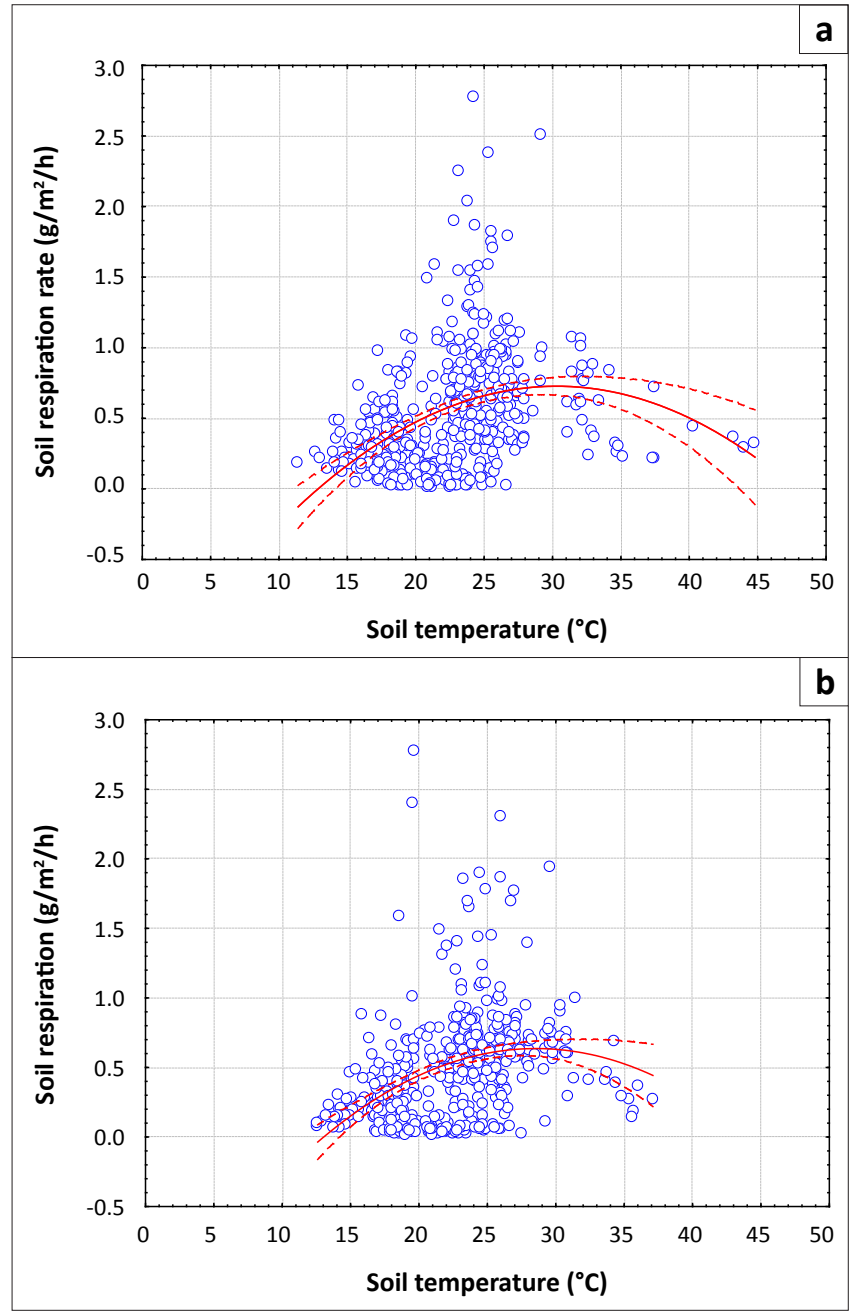

FIGURE 1: Effect of soil temperature on the rate of soil $\mathrm{CO}_{2}$ respiration in the (a) Acacia savannas $\left(R^{2}=0.153\right)$ and (b) Combretum savannas $\left(R^{2}=0.154\right)$. Maximum respiration peaks at about $28{ }^{\circ} \mathrm{C}$ and then declines. The dots are data and the solid line represents the fitted polynomial regression curve at $95 \%$ confidence interval (dashed lines). measured in November, with means ( \pm s.d.) measured at $1.053 \mathrm{~g} / \mathrm{m}^{2} / \mathrm{h} \pm 0.575 \mathrm{~g} / \mathrm{m}^{2} / \mathrm{h}$ in the Acacia savanna and $0.5830 \mathrm{~g} / \mathrm{m}^{2} / \mathrm{h} \pm 0.329 \mathrm{~g} / \mathrm{m}^{2} / \mathrm{h}$ in the Combretum savanna. The corresponding mean ( \pm s.d.) monthly volumetric soil moisture was $7.4 \% \pm 3.0 \%$ in the Acacia savanna compared to $5.1 \% \pm 1.8 \%$ in the Combretum savanna (see Table 1). For the Acacia savanna data show a linear increase with increasing soil moisture content, reaching a plateau above $10 \%$ moisture content. For the Combretum savanna data show a more-orless linear increase with increasing soil moisture content, without a plateau.

\section{Combined effects of soil temperature and moisture on soil respiration}

Respiration responses to increases in soil temperature have been shown to be constrained by soil moisture (e.g. Conant $e t$ al. 2004). Multiple regressions, considering both moisture and temperature effects and their interactions, account for nearly two-thirds of the variance in the data at both the Acacia and Combretum savanna sites (Figures $3 a$ and $b$ ). The two sites differed in their soil moisture characteristics $(p<0.0001)$ but not with regard to temperature $(p=0.141)$, suggesting that soil moisture is the key factor controlling soil respiration in these savannas.

\section{Relationship between soil respiration and the fraction of absorbed photosynthetically available radiation}

The results showed a strong seasonal variation in the rate of soil respiration in both the Acacia and Combretum savannas $(p=0.028)$ (see Table 1 and Figure 4a). Soil respiration rate and FAPAR both peaked during the wet season (summer months) and were lower in the dry season (winter months). The observed trend is likely due to the combined effects of 

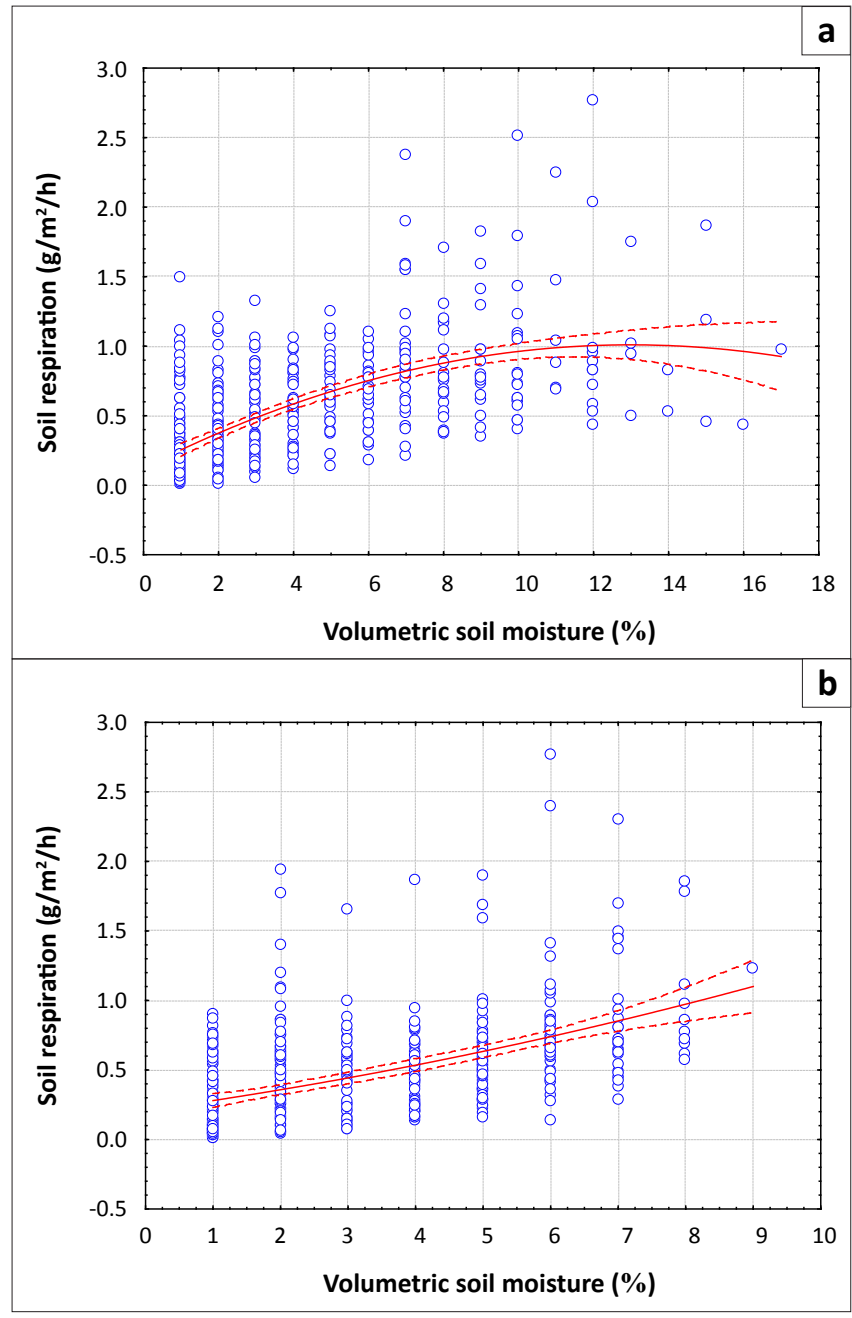

FIGURE 2: Effect of soil moisture on the rate of (a) respiration in the Acacia savanna $\left(R^{2}=0.380\right)$ and (b) soil CO respiration in the Combretum savanna $\left(R^{2}=0.259\right)$. The dots are actual data and the solid line represents the fitted linear regression at the $95 \%$ confidence interval (dashed lines).

seasonal patterns of soil moisture and temperature. In our study period, soil respiration (Figure 4a) and FAPAR (Figure $4 \mathrm{~b})$ both began to increase after September, when the rain began, and not July, the coldest month. Respiration reached a maximum in November, whilst FAPAR response lagged by a month, reaching its maximum value in December (Figure 4b).

\section{Discussion}

\section{Effects of soil temperature and moisture on the rate of soil respiration}

Our study corroborates findings of other studies, which have shown that soil respiration is greatest at around $25{ }^{\circ} \mathrm{C}$ (e.g. Conant et al. 2004). At this temperature microbes are active but the temperature is not too high to retard their activity (Swift, Heal \& Anderson 1979). Our study found that when soil temperatures rose above $28^{\circ} \mathrm{C}$, soil respiration declined, but this observation is confounded by the low soil moisture, which always coincided with high temperatures. Temperature dependence of respiration therefore remains unclear at the site, as also reported by Williams et al. (2009), although results from Kutsch et al. (2008) suggest

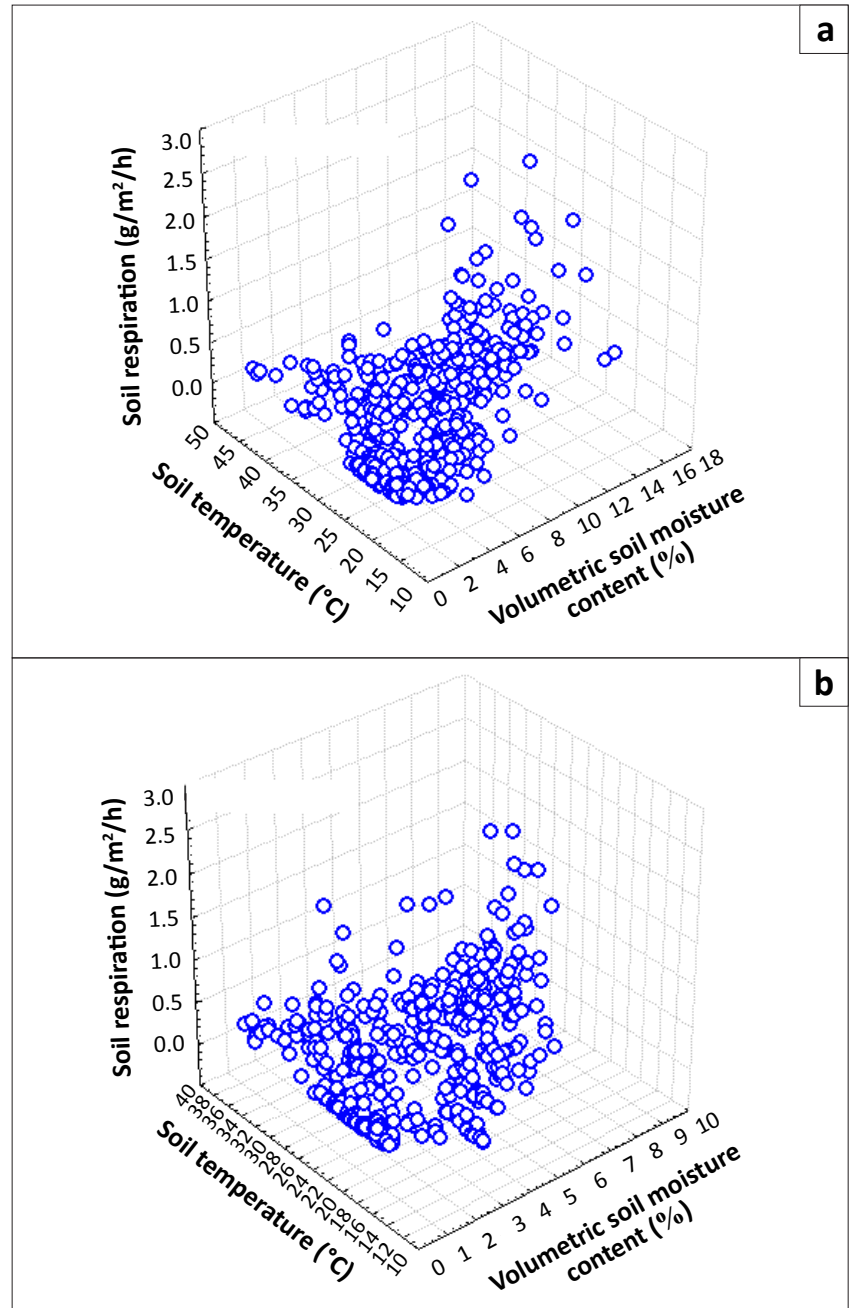

FIGURE 3: Effects of soil temperature and moisture on the rate of soil respiration in the Acacia (a) and Combretum (b) savannas. Multiple regression $[R(z / x y)]$ shows that soil moisture and temperature jointly explain a major fraction of the variation in respiration in the Acacia $(R=0.647)$ and Combretum $(R=0.636)$ sites.

that respiration suppression at high temperatures may be occurring. $Q_{10}$ is defined, by convention, as the factor by which respiration increases over a 10-degree temperature range, but can be calculated over any temperature difference, and can be thought of as the sensitivity of respiration to temperature at any given temperature. We calculated it for several temperature ranges. Similar to the results of Wang et al. (2010), we show a $Q_{10}$ value of more than 1 in both sites at all temperature ranges analysed, but which declines at higher temperature. The decline of $Q_{10}$ at high temperatures has also been observed by several other researchers (e.g. Allison, Wallenstein \& Bradford 2010; Bradford et al. 2008; Chen \& Tian 2005). This decline at high temperature may be due to a temperature-moisture relationship (Williams et al. 2009; Xu \& Baldocchi 2004; Xu et al. 2004), metabolic processes (White 2003) and ecosystem self-adjustment on a long time scale (Davidson \& Janssens 2006).

The moisture content of the soil is dependent on the rate of water lost through evapotranspiration and drainage. The temperature regime of soils is greatly affected by their moisture content. Skopp, Jawson and Doran (1990) found that microbial activity depends on soil water content to 

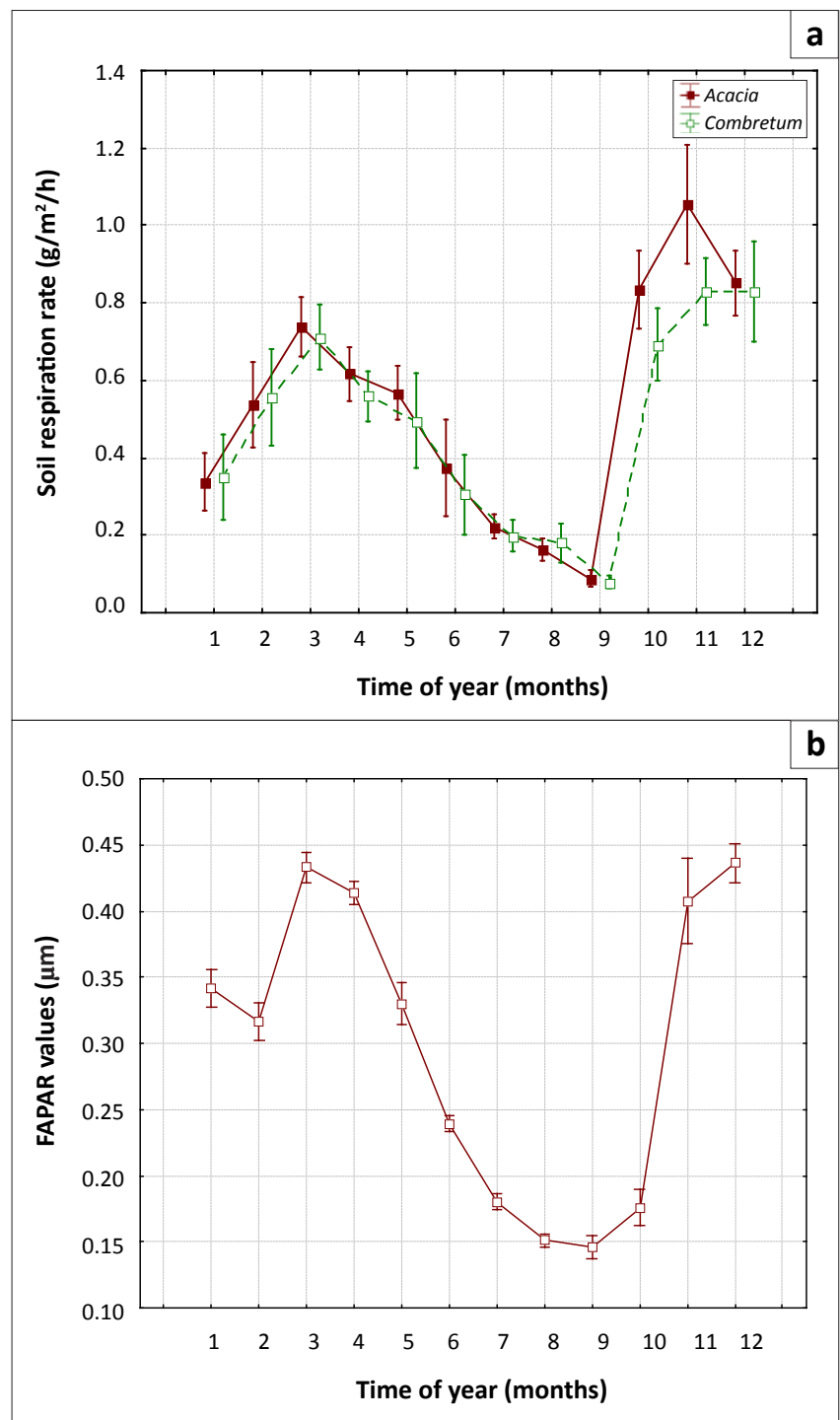

FIGURE 4: Relationship between (a) mean monthly soil respiration rate in the Acacia and Combretum savannas and (b) fraction of absorbed photosynthetically active radiation (FAPAR) values over 12 consecutitve months. Months are numbered according to the calendar year.

function properly. Increases in soil moisture tend to optimise soil temperature, which, in turn, enhances the decomposition of organic matter by soil microorganisms and thus increases the rate of soil respiration. Increased respiration following wetting as reported here was also observed in the same site by Williams et al. (2009) and similar findings have been reported in other water-limited ecosystems (e.g. Jenerette, Scott \& Huxman 2008; Xu \& Baldocchi 2004; Xu et al. 2004).

This study concludes that soil moisture is the main factor responsible for the differences in respiration rates between Acacia and Combretum savannas, which concur with findings by Zhang et al. (2003) and Xu et al. (2004). However, it should also be noted that soil respiration is also influenced by the amount of soil carbon (i.e. the respiration substrate), which is typically low in savannas (Montgomery \& Askew 1980; Scholes 1990). The typically sandy savanna soils have a low potential for stabilising carbon; the high temperatures common in savanna systems promote soil respiration. Furthermore, a significant fraction of the carbon is also lost to fire and herbivory before it can enter the soil (Scholes \& Van der Merwe 1996).

\section{Relationship between soil respiration and the fraction of absorbed photosynthetically available radiation}

One way to tease out the autotrophic from the heterotrophic components of soil respiration is to look at the degree to which soil respiration is coupled to plant activity, indexed for instance by FAPAR. Our findings agree with those of Wang et al. (2010), who concluded from a number of studies that seasonal vegetation activity plays an important role in the seasonal variation of soil respiration. The variation of soil respiration in the growing season in, for instance, a temperate forest is mainly determined by variations of root respiration in response to seasonal temperature changes (Boone et al. 1998). Variations in plant phenology significantly contributed to the variations in calculated seasonal $Q_{10}$ values of soil respiration in a mixed temperate forest (Curiel Yuste et al. 2004), which were later attributed directly to seasonal differences in ecosystem photosynthesis (Sampson et al. 2007).

Soil moisture variability between Acacia and Combretum savannas is fundamentally due to the difference in soil types, given that both receive the same rainfall (there is some downslope movement of water from the sandy soils to the clays soils). The clayey Acacia soils retain moisture longer than the sandy soils at the Combretum site. Fine-textured soils tend to have a higher SOM content and decomposition rate than coarse-textured soils (Schimel, Stillwell \& Woodmansee 1985). The result is a higher respiration rate in the clayey, broad-leaved Acacia savannas than in the sandy, fine-leaved Combretum savannas.

A recent study suggests that the effect of variations in seasonal amplitude of vegetation activity on the variation of seasonally derived $Q_{10}$ is higher than that of climatic variables such as temperature and precipitation, which highlights the linkage between plant physiological processes and soil processes (Wang et al. 2010). Vegetation activities may therefore substantially stimulate seasonal $Q_{10}$ of soil respiration (Wang et al. 2010).

\section{Conclusion}

This study showed that the highest rate of soil respiration in the Acacia and Combretum savannas was measured at a soil temperature of $28^{\circ} \mathrm{C}$. We observed that soil respiration is always low at much higher temperatures, but because high temperature was always associated with very low soil moistures, we cannot come to any definitive conclusion about the effect of high temperature on soil respiration from this field study alone - it will require a manipulative experiment. Because the soil temperature at this site is generally quite warm, even in winter, the availability of soil moisture is the primary control factor of soil respiration. Respiration had a positive linear response to increasing soil moisture in both the Acacia and Combretum savannas. Respiration responds more rapidly to soil wetting by rain than FAPAR does, 
which seems to lag by about a month, suggesting that root respiration is a relatively small part of the observed flux. Respiration rate was $15 \%$ higher in the Acacia site than in the Combretum site, which corresponds to the difference in observed volumetric soil moisture content. Other factors that might have influenced respiration variation amongst the two sites include substrate inputs, soil texture and percentage SOM.

\section{Acknowledgements}

We acknowledge the financial support received from the CSIR Parliamentary Grant Funding to the Natural Resources and Environment Division and the EU CarboAfrica Grant Funding to the CSIR Ecosystem Processes and Dynamics Unit. Dr Sally Archibald from the CSIR is acknowledged for her invaluable comments and inputs to this paper. Heleen de Beer from the CSIR is acknowledged for proofreading the manuscript. Musa Mavundla is thanked for field surveys and data collection. We also appreciate comments and suggestions by two anonymous reviewers.

\section{Authors' contributions}

R.A.M. analysed data and collected supplementary data. R.J.S. designed and supervised the study.

\section{References}

Ågren, G.I., Kirschbaum, M.U.F., Johnson, D.W. \& Bosatta, E., 1996, 'Ecosystem physiology - soil organic matter', in A.I. Breymeyer, D.O. Hall, J.M. Melillo \& G.I. Ågren (eds.), Global change: Effects on Coniferous Forests and Grasslands, pp. 207-228, John Wiley \& Sons, Chichester.

Allison, S.D., Wallenstein, M.D. \& Bradford, M.A., 2010, 'Soil-carbon response to warming dependent on microbial physiology', Nature Geoscience 3, 336-340. doi:10.1038/ngeo846

Anderson, D.W., 1995, 'The role of nonliving organic matter in soils', in R.G. Zepp \& Ch. Sonntag (eds.), The role of nonliving organic matter in the Earth's carbon cycle, pp. 81-92, John Wiley \& Sons, Chichester.

Bond-Lamberty, B. \& Thomson, A., 2010, 'A global database of soil respiration data', Biogeosciences Discussion 7, 1321-1344. doi:10.5194/bgd-7-1321-2010

Boone, R.D., Nadelhoffer, K.J., Canary, J.D. \& Kaye, J.P., 1998, 'Roots exert a strong influence on the temperature sensitivity of soil respiration', Nature 396, 570-572. influence on the tempe
doi:10.1038/25119

Bradford, M.A., Davies, C.A., Frey, S.D., Maddox, T.R., Melillio, J.M., Mohan, J.E. et al., 2008, 'Thermal adaptation of soil microbial respiration to elevated temperature', Ecological Letters 11, 1316-1327. doi:10.1111/j.1461-0248.2008.01251.x, PMid: 19046360

Chen, H. \& Tian, H-Q., 2005, 'Does a general temperature-dependent $Q_{10}$ model of soil respiration exist at biome and global scale?', Journal of Integrative Plant Biology 47, 1288-1302. doi:10.1111/j.1744-7909.2005.00211.x

Conant, R.T., Dalla-Betta, P., Klopatek, C.C. \& Klopatek, J.M., 2004, 'Controls on soil respiration in semiarid soils', Soil Biology and Biochemistry 36, 945-951. doi:10.1016/j.soilbio.2004.02.013

Curiel Yuste, J., Janssens, I.A., Carrara, A. \& Ceulemans, R., 2004, 'Annual Q(10) of soil respiration reflects plant phenological patterns as well as temperature sensitivity' Global Change Biology 10, 161-169. doi:10.1111/j.1529-8817.2003.00727.x

Davidson, E.A. \& Janssens, I.A., 2006, 'Temperature sensitivity of soil carbon decomposition and feedbacks to climate change', Nature 440, 165-173. doi:10.1038/nature04514, PMid:16525463

Davidson, E.A., Belk, E. \& Boone, R.D., 1998, 'Soil water content and temperature as independent or confounded factors controlling soil respiration in a temperate mixed hardwood forest', Global Change Biology 4, 217-227. doi:10.1046/j.13652486.1998.00128.x

Fan, S.M., Goulden, M.L., Munger, J.W., Daube, B.C., Bakwin, R.S., Wofsy, S.C. et al. 1995, 'Environmental controls on the photosynthesis and respiration of a boreal lichen woodland: a growing season of whole-ecosystem exchange measurements by eddy correlation', Oecologia 102, 443-452. doi:10.1007/BF00341356

Houghton, R.A. \& Woodwell, G.M., 1989, 'Global climate change', Scientific American 260, 36-44. doi:10.1038/scientificamerican0489-36

Houghton, R.A., 1995, 'Balancing the global carbon cycle with terrestrial ecosystems', in R.G. Zepp \& Ch. Sonntag (eds.), The role of nonliving organic matter in the Earth's carbon cycle, pp. 133-152, John Wiley \& Sons, Chichester.
Intergovernmental Panel of Climate Change, 2001, Climate Change 2001: The scientific basis. Contribution of Working Group I to the Third Assessment Report of the Intergovernmental Panel on Climate Change, Cambridge University Press, of the Intergov
Cambridge.

Jarvis, P.G. \& Leverenz, J.W., 1983, 'Productivity of temperate, deciduous and evergreen forests', in O.L. Lange, P.S. Nobel, C.B. Osmond \& H. Ziegler (eds.), Physiological plant ecology IV, pp. 233-280, Springer, Berlin.

Jenerette, G.D., Scott, R.L. \& Huxman, T.E., 2008, 'Whole ecosystem metabolic pulses following precipitation events', Functional Ecology 22, 924-930. doi:10.1111/ j.1365-2435.2008.01450.x

Jones, C.D. \& Cox, P.M., 2001, 'Constraints on the temperature sensitivity of global soil respiration from the observed interannual variability in atmospheric $\mathrm{CO}_{2}$ ' Atmospheric Science Letters 2, 166-172. doi:10.1006/asle.2001.0041

Kirschbaum, M.U.F., 1995, 'The temperature dependence of soil organic matter decomposition, and the effect of global warming on soil organic C storage', Soil Biology and Biochemistry 27, 753-760. doi:10.1016/0038-0717(94)00242-S

Kutsch, W.L., Hanan, N., Scholes, B., Mchugh, I., Kubheka, W., Eckhardt, H. et al., 2008, 'Response of carbon fluxes to water relations in a savanna', Biogeosciences Discussion 5, 1797-1808. doi:10.5194/bgd-5-2197-2008

Lavigne, M.B., Ryan, M.G., Anderson, D.E., Baldocchi, D.D., Crill, P.M., Fitzjarrald, D.R. et al., 1997, 'Comparing nocturnal eddy covariance measurements to estimates of ecosystem respiration made by scaling chamber measurements at six coniferous boreal sites', Journal of Geophysical Research 102, 28977-28985. six coniferous boreal sites,
doi:10.1029/97JD01173 Luo, Y., Wan, S. \& Hui, D., 2001, 'Acclimatization of soil respiration to warming in a
tall grass prairie', Nature 413, 622-625. doi:10.1038/35098065, PMid:11675783

Mäkelä, A., Pulkkinen, M.A., Kolari, P., Largergren, F., Berbigier, P., Lindroth, A. et al., 2008, 'Developing an empirical model of stand GPP with the LUE approach: Analysis of eddy covariance data at five contrasting confier sites in Europe', Global Change Biology 14, 92-108.

Montgomery, R.F. \& Askew, G.P., 1980, 'Soils of tropical savannas', in F. Bourlier (ed.), Ecosystems of the World 13: Tropical savannas, pp. 63-78, Elsevier, Amsterdam.

Otter, L.B., Guenther, A. \& Greenberg, J., 2002, 'Seasonal and spatial variations in biogenic hydrocarbon emissions from southern African savannas and woodlands', Atmospheric Environment 36, 4265-4275. doi:10.1016/S1352-2310(02)00333-3

Peng, S.S., Piao, S.L., Wang, T., Sun, J. \& Shen, Z., 2009, 'Temperature sensitivity of soil respiration in different ecosystems in China', Soil Biology and Biochemistry 41 1008-1014. doi:10.1016/j.soilbio.2008.10.023

Prentice, I.C., Farquhar, G.D., Fasham, M.J.R., Goulden, M.L., Heimann, M., Jaramillo, V.J. et al., 2001, 'The carbon cycle and atmospheric carbon dioxide', in J.T. Houghton, Y. Ding, D.J. Griggs, M. Noguer, P.J. van der Linden, X. Dai et al. (eds.), Climate Change 2001: The Scientific Basis. Contribution of Working Group I to the Climate Change 2001: The Scientific Basis. Contribution of Working Group I to the
Third Assessment Report of the Intergovernmental Panel on Climate Change, pp. Third Assessment Report of the Intergovernmental
183-237, Cambridge University Press, Cambridge.

Raich, J.W. \& Potter, C., 1995, 'Global patterns of carbon dioxide emissions from soil', Global Biogeochemical Cycle 9, 23-36. doi:10.1029/94GB02723

Raich, J.W. \& Schlesinger, W.H., 1992, 'The global carbon dioxide flux in soi respiration and its relationship to vegetation and climate', Tellus 44, 81-99. doi:10.1034/j.1600-0889.1992.t01-1-00001.x

Raich, J.W. \& Tufekcioglu, A., 2000, 'Vegetation and soil respiration: correlations and controls', Biogeochemistry 48, 71-90. doi:10.1023/A:1006112000616

Raich, J.W., Potter, C. \& Bhagawati, D., 2002, 'Interannual variability in global soil respiration, 1980-94', Global Change Biology 8, 800-812. doi:10.1046/j.13652486.2002.00511.x

Reichstein, M. \& Beer, C., 2008, 'Soil respiration across scales: The importance of model data integration framework for data interpretation', Journal of Plant Nutrition and Soil Science 171, 344-354. doi:10.1002/jpln.200700075

Reichstein, M., Rey, A., Freibauer, A., Tenhunen, J.D., Valentini, R., Banza, J. et al., 2003, 'Modeling temporal and large-scale spatial variability of soil respiration from soil water availability, temperature and vegetation productivity indices', Global Biogeochemical Cycle 17, 1104-1115. doi:10.1029/2003GB002035

Roxburgh, S.H., Berry, S.L., Buckley, T.N., Barnes, B. \& Roderick, M.L., 2005, 'What is NPP? Inconsistent accounting of respiratory fluxes in the definition of net primary production', Functional Ecology 19, 378-382. doi:10.1111/j.13652435.2005.00983.x

Sampson, D.A., Janssens, I.A., Curiel Yuste, J. \& Ceulemans, R., 2007, 'Basal rates of soil respiration are correlated with photosynthesis in a mixed temperate forest', Global Change Biology 13, 2008-2017. doi:10.1111/j.1365-2486.2007.01414.x

Schimel, D., Stillwell, M.A. \& Woodmansee, R.G., 1985, 'Biogeochemistry of C, $\mathrm{N}$, and $\mathrm{P}$, in a soil catena of the shortgrass steppe', Ecology 66, 276-282. doi:10.2307/1941328

Schimel, D.S., 1995, 'Terrestrial ecosystems and the carbon cycle', Global Change Biology 1, 77-91. doi:10.1111/j.1365-2486.1995.tb00008.x

Schlesinger, W.H., 1977, 'Carbon balance in terrestrial detritus', Annual Review of Ecology and Systematics 8, 51-81. doi:10.1146/annurev.es.08.110177.000411

Scholes, R.J. \& Van der Merwe, M.R., 1996, 'Sequestration of carbon in savannas and woodlands', Environmental Professionals 18, 96-103.

Scholes, R.J. \& Walker, B.H., 1993, An African savanna: synthesis of the Nylsvley Study, Cambridge University Press, Cambridge. doi:10.1017/СBO9780511565472

Scholes, R.J., 1990, 'The influence of soil fertility on the ecology of southern African dry savannas', Journal of Biogeography 17, 415-419. doi:10.2307/2845371

Scholes, R.J., Gureja, N., Giannecchinni, M., Dovie, D., Wilson, B., Davidson, N. et al., 2001, 'The environment and vegetation of the flux measurement site near Skukuza, Kruger National Park', Koedoe 44, 73-83. 
Skopp, J., Jawson, M.D. \& Doran, J.W., 1990, 'Steady-state aerobic microbial activity as a function of soil water content', Soil Science Society of America Journal 54 1619-1625. doi:10.2136/sssaj1990.03615995005400060018x

Swift, M.J., Heal, O.W. \& Anderson, J.M., 1979, Decomposition in terrestrial ecosystem (Studies in ecology), University of California Press, Berkeley. PMCid:1638109

Townsend, A.R., Vitousek, P.M. \& Holland, E.A., 1992, 'Tropical soils could dominate the short-term carbon cycle feedbacks to increased global temperatures', Climate Change 22, 293-303. doi:10.1007/BF00142430

Veenendaal, E.M., Kolle, O. \& Lloyd, J., 2004, 'Seasonal variation in energy fluxes and carbon dioxide exchange for a broad-leaved semi-arid savanna (Mopane woodland) in Southern Africa', Global Change Biology 10, 318-328. doi:10.1111/ j.1365-2486.2003.00699.x

Venter, F.J., 1990, 'A classification of land for management planning in the Kruge National Park', PhD thesis, University of South Africa.

Vincent, G., Shahriari, A.R., Lucot, E., Badot, P.M. \& Epron, D., 2006, 'Spatial and seasonal variations in soil respiration in a temperate deciduous forest
with fluctuating water table', Soil Biology and Biochemistry 38, 2527-2535. doi:10.1016/j.soilbio.2006.03.009

Wang, X., Piao, S., Ciais, P., Janssens, I.A., Reichstein, M., Peng, S. et al., 2010, 'Are ecological gradients in seasonal Q10 of soil respiration explained by climate or by vegetation seasonality?', Soil Biology and Biochemistry. doi:10.1016/j. soilbio.2010.06.008

Watson, R.T., Noble, I.R., Bolin, B., Ravindranath, N.H., Verardo, D.J. \& Dokken D.J., 2000, Land use, land-use change and forestry: A special report of the Intergovernmental Panel of Climate Change (IPCC), Cambridge University Press, Cambridge.
Webster, K.L., Creed, I.F., Beall, F.D. \& Bourbonnière, R.A., 2008, 'Sensitivity of catchment aggregated estimates of soil carbon dioxide efflux to topography under different climatic conditions', Journal of Geophysical Research and Biogeosciences different climatic conditions', Journal of Geoph

White, J.W., 2003, Modelling temperature response in wheat and maize: Proceedings of a workshop, CIMMYT, EL Batán, Mexico, 23-25 April 2001, p.p. 8-22, International Maize and Wheat Improvement Center (CIMMYT), Mexico.

Williams, C.A., Hanan, N., Scholes, R.J. \& Kutsch, W., 2009, 'Complexity in water and carbon dioxide fluxes following rain pulses in an African savanna', Oecologia 161 469-480. doi:10.1007/s00442-009-1405-y, PMid:19582479, PMCid:2757614

Xu, L.K. \& Baldocchi, D.D., 2004, 'Seasonal variation in carbon dioxide exchange over a Mediterranean annual grassland in California', Agricultural and Forest Meteorology 123, 79-96. doi:10.1016/j.agrformet.2003.10.004

Xu, L.K., Baldocchi, D.D. \& Tang, J., 2004, 'How soil moisture, rain pulses, and growth alter the response of ecosystem respiration to temperature', Global Biogeochemical Cycle 18, GB4002. doi:10.1029/2004GB002281

Zhang, Y., Ling-Hao, L., Fang, T., Quan-Sheng, C., Jing, Y., Zhi-You, Y. et al., 2003, Comparison of soil respiration in two grass-dominated communities in the Xilin River Basin', Acta Botanica Sinica 45, 1024-1029.

Zheng, Z-M., Yu, G-R., Fu, Y-L., Wang, W-S., Sun, X-M. \& Wang, Y-H., 2009, 'Temperature sensitivity of soil respiration is affected by prevailing climatic conditions and soil organic carbon content: A trans-China based case study', Soil Biology and Biochemistry 41, 1531-1540. doi:10.1016/j.soilbio.2009.04.013 